\title{
TEISINĖS PASTANGOS SUREGULIUOTI LIETUVOS VYRIAUSIOJO KARO VADO IR KARIUOMENĖS VADO PAVALDUMĄ KRAŠTO APSAUGOS MINISTRUI, MINISTRUI PIRMININKUI IR RESPUBLIKOS PREZIDENTUI 1918-1940 M.
}

\author{
Kęstutis Kilinskas \\ Vilniaus universiteto Istorijos fakultetas
}

Istoriografijoje plačiai žinomas ir gausiai cituojamas 1935 m. išleistas Lietuvos kariuomenès vadovybès ịstatymas. Pagrindines šio įstatymo nuostatas gana nuodugniai pristatė ir aptaré dauguma Lietuvos kariuomenès istoriją tiriančių mokslininkų, tarp jų - Jonas Vaičenonis ${ }^{1}$, Vytenis Statkus ${ }^{2}$, Vytautas Lesčius ${ }^{3}$ ir Gintautas Surgailis.. Tyrinejjant šias mokslines publikacijas aiškejja, kad dažniausiai analizuojant minètąji ịstatymą apsiribojama svarbiausiųjų Respublikos Prezidento, krašto apsaugos ministro ir kariuomenès vado teisių ir pareigų pristatymu ir nesigilinama ị jo rengimo politines aplinkybes, nesiimama šio įstatymo analizuoti platesniame Lietuvos politinès santvarkos kontekste, nesiryžtama nuodugniau aptarti jo santykio su pagrindiniu valstybès dokumentu - Konstitucija ir juo labiau nemėginama ieškoti šio įstatymo pirmtakų arba jo projektų.

Taigi šiame straipsnyje imsimės savotiškos $1935 \mathrm{~m}$. paskelbto kariuomenès vadovybès ịstatymo genezès - analizuosime krašto apsaugos ministro, vyriausiojo karo vado ir kariuomenès vado (karinès vadovybès) pavaldumą (subordinaciją) Respublikos Prezidentui ir ministrui pir-

1 Jonas Vaičenonis, Kariuomenè, Lietuvos Nepriklausomybe, t. X, 1 d., sud. Danutė Blaužytė-Bužienè, Edmundas Gimžauskas, Česlovas Laurinavičius, Dangiras Mačiulis, Gediminas Rudis, Artūras Svarauskas, Jonas Vaičenonis, Vilnius, 2013, p. 590.

2 Vytenis Statkus, Lietuvos ginkluotosios pajégos 1918-1940, Čikaga, 1986, p. 386-387.

3 Vytautas Lesčius, Lietuvos kariuomene Nepriklausomybès kovose 1918-1920, Vilnius, 1998, p. 86-90.

4 Gintautas Surgailis, Lietuvos kariuomene 1918-1940, Vilnius, 1998, p. 39-41; Lietuvos kariuomenès vadai, sud. Gintautas Surgailis, Vilnius, 1992, p. 143. 
mininkui (politinei vadovybei) reguliuojančius teisès aktus ir jų santyki su Lietuvos Respublikos Konstitucija ir politine santvarka. Taip pat atskleisime, kaip keitèsi kariuomenès vadovybès subordinacija politinei valdžiai Nepriklausomybės kovų, demokratinio ir autoritarinio valstybės valdymo laikotarpiais.

Tyrimas parengtas remiantis Lietuvos centriniame valstybès archyve Krašto apsaugos ministerijos (f. 384) ir Kariuomenès štabo (f. 929) fonduose rastais ir iki šiol Lietuvos istoriografijoje nežinomais kariuomenès vadovybès subordinaciją ir valdymą apibrèžiančių ịstatymų projektais, jų rengèjų posèdžių protokolais ir karinèje periodikoje publikuotais kariškių komentarais. Politinès diskusijos ir politinių partijų požiūris ị tokio pobūdžio įstatymuose ir teisès aktuose numatytas nuostatas rekonstruojamas remiantis Steigiamojo Seimo stenogramomis ${ }^{5}$ ir Valstybès Tarybos posèdžių protokolais ${ }^{6}$. Itin svarbūs šaltiniai, be kurių tokio pobūdžio tyrimas būtų neịmanomas, yra valstybès teisès aktai, Lietuvos konstitucijos, Ypatingieji valstybès apsaugos ịstatai ir Stojimo ị krašto apsaugos tarnybą taisyklès, publikuotos laikraštyje „Laikinosios vyriausybės žinios“. Lietuvos konstitucijos tiriamos remiantis teisès istorikų Mindaugo Maksimaičio, Stasio Vansevičiaus ${ }^{7}$ ir Kazimiero Valančiaus ${ }^{8}$ monografijomis. Dalị straipsnyje analizuojamų teisinių problemų, susijusių su Ypatingaisiais valstybès apsaugos ịstatais ir karo justicija, istoriniuose tyrimuose palietė Modestas Kuodys ir Andriejus Stoliarovas. M. Kuodys, analizuodamas karo padèties režimą tarpukario Lietuvoje, aptarė Ypatinguosius valstybès apsaugos ịstatus ir jų turinị. Daugiausia dėmesio jis skyrė teisiniams karo padèties režimo aspektams ${ }^{9}$, tačiau politinių jègų ir karininkijos konfliktų, dariusių ịtaką kariuomenès vadų ir politikų santykių teisiniam sureguliavimui, o kartu ir Ypatingųjų valstybès apsaugos ịstatu koregavimo niuansų nenagrinejjo. Lietuvos kariuomenès justicijos tyrëjo

5 Steigiamojo Seimo darbai, sąsiuviniai nr. 21-32, Kaunas, 1921; Steigiamojo Seimo darbai, sąsiuviniai nr. 33-42, Kaunas, 1922.

6 Lietuvos Valstybès Tarybos protokolai 1917-1918 m., sud. A. Eidintas, R. Lopata, Vilnius, 1991.

7 M. Maksimaitis, S. Vansevičius, Lietuvos valstybès ir teisés istorija, Vilnius, 1997.

8 Kazimieras Valančius, Lietuvos valstybès konstitucijos, Vilnius, 1989.

9 Modestas Kuodys, Karo padèties režimas Lietuvos Respublikoje 1919-1940 m., daktaro disertacija, Kaunas, 2008. 
Andriejaus Stoliarovo tyrimai apima ne tik karinių teisminių institucijų veiklą ${ }^{10}$, karininkų garbès teismo ${ }^{11}$ ir baudžiamosios teisès ${ }^{12}$ analizę, bet ir kariuomenès teisinio reguliavimo vidaus neramumams malšinti klausimus $^{13}$, taip pat atskleidžia Lietuvos kariuomenès teisètvarkos ir justicijos principų santyki su tarpukario Rusijos imperijoje galiojusia teise. Šiu autorių tyrimais pasinaudota ir šiame darbe. Karininkijos nuomonè ir požiūris ị $1935 \mathrm{~m}$. kariuomenès vadovybès įstatymą atskleistas remiantis Stasio Raštikio ${ }^{14}$ atsiminimais ir Juozo Aničo parengta Jurgio Bobelio ${ }^{15}$ biografija, karininkų atsiliepimais ir straipsniais „Kario“, „Kardo“ ir „Mūsų žinyno“ žurnaluose.

\section{VALSTYBĖS TARYBOS IR VYRIAUSYBĖS KONFLIKTO İTAKA TEISINIAM POLITINĖS IR KARINĖS VADOVYBĖS SANTYKIŲ NUSTATYMUI}

Pagal 1918 m. lapkričio 2 d. Lietuvos Tarybos priimtus Lietuvos Valstybès Konstitucijos pamatinius dèsnius, Lietuvos kariuomenė buvo Valstybės Tarybos prezidiumo, kuris turejjo teisę skirti vyriausiąji karo vadą ir aukštuosius kariuomenès valdininkus, žinioje ${ }^{16}$. Nors svarstant šiuos dèsnius Jonas Vileišis iškèlè idèją, kad kariuomenẻ turi būti palikta Valstybès Tarybos žinioje, motyvuodamas tuo, kad „Prezidiumas gali suvartoti

10 Andriejus Stoliarovas, Lietuvos Respublikos karine justicija 1919-1940 m., Kaunas, 2014; A. Stoliarovas, Lietuvos Respublikos kariniai teismai 1919-1940 m., daktaro disertacija, Kaunas, 2012.

11 Andriejus Stoliarovas, „Kariško munduro“ garbės gynimas prieškario Lietuvoje, Lietuvos istorijos metraštis, 2011, t. 1, p. 63-80.

12 Andriejus Stoliarovas, Pirmosios Lietuvos Respublikos specialiosios baudžiamosios teisès šaltiniai. Rusijos imperijos 1869 m. karo įstatymų sąvadas: recepcija ir novelizacija, Istorija, nr. 79, 2010, p. 28-43.

13 Andriejus Stoliarovas, Vidiniai neramumai Lietuvos Respublikoje 1919-1940 m., Acta historica Universitatis Klaipedensis, t. XXXII, 2016, p. 102-103.

14 Stasys Raštikis, Kovos dèl Lietuvos Nepriklausomybès, t. 1, Vilnius, 1990; Stasys Raštikis, Ivykiai ir žmonés, t. 4, Čikaga, 1972.

15 Jonas Aničas, Karo komendantas Jurgis Bobelis, Vilnius, 2011.

16 Kazimieras Valančius, Lietuvos valstybès konstitucijos, Vilnius, 1989, p. 7. 
kariuomenę prieš Tarybą "17, balsuojant šiam pasiūlymui nebuvo pritarta ir Lietuvos kariuomenė tapo pavaldi Valstybès Tarybos prezidiumui. Tai buvo vienintelè teisinè nuostata, apibrèžianti kariuomenès politinę subordinaciją. Kaip rodo 1919 m. gruodžio mèn. Krašto apsaugos ministerijos įsakymų, kuriais remiantis ị pareigas skiriami aukšti kariuomenès karininkai, analizė, Valstybės Tarybos prezidiumas savo konstitucinę pareigą vykdẻ kontrasignuodamas ${ }^{18}$ krašto apsaugos ministro įsakymus, kurie buvo išleidžiami „sulig Valstybès prezidiumo žinia“19. Tai reiškia, kad Valstybès Taryba teisę valdyti kariuomenę realizavo per Krašto apsaugos ministeriją. Tačiau 1919 m. sausio mèn. Tarybos prezidiumo ir vyriausybės santykiai ima keistis: kairiosios politinès jègos, perèmusios iniciatyvą valstybės kuriamajame darbe, siekè sustiprinti savo politines pozicijas ir perrinkti Valstybės Tarybos atstovus, o Taryba - priversti vyriausybę laikytis Laikinosios Konstitucijos. Tarp politinès valdžios institucijų atsiradusi ịtampa pradeda atsispindèti ir kariuomenès vadovybės politinę subordinaciją nustatančiuose įsakymuose. Mykolo Sleževičiaus vyriausybė, norėdama parodyti augančią politinę galią ir ateityje tikèdamasi ịgyti teisę valdyti kariuomenę, pradejjo skelbti vyriausybès nutarimus $^{20}$ kariuomenei, kas rodè vyriausybès sustiprejusias pozicijas, palyginti su Valstybès Taryba.

1919 m. sausio mèn. svarbiu veiksniu Tarybos ir vyriausybės kovoje tapo kariuomenès daliniai: 2-asis pèstininkų pulkas, deklaravęs ištikimybę Valstybès Tarybai, atsisakè paklusti vyriausybei, o Kauno komendan-

17 Raimondas Lopata, Alfonsas Eidintas, Lietuvos Valstybes Tarybos protokolai 19171918, Vilnius, 1991, p. 359.

18 Isakymas Krašto apsaugos ministerijai, 1919 m. gruodžio 1 d., LCVA, f. 383, ap. 7, b. 52, 1. 7; İsakymas Krašto apsaugos ministerijai, 1919 m. gruodžio 10 d., LCVA, f. 383, ap. 7, b. 52, 1. 4-5; İsakymas Krašto apsaugos ministerijai, 1919 m. gruodžio 26 d., LCVA, f. 383 , ap. 7, b. 52, 1. 8; İsakymas Krašto apsaugos ministerijai, 1919 m. gruodžio 26 d., LCVA, f. 383, ap. 7, b. 52, 1. 30.

19 İsakymas Krašto apsaugos ministerijai, 1919 m. gruodžio 24 d., LCVA, f. 383, ap. 7, b. $52,1.6$.

${ }^{20}$ Krašto apsaugos ministro įsakymas, 1919 m. sausio 9 d., LCVA, f. 383, ap. 7, b. 52, 1. 11; Krašto apsaugos ministro ịsakymas, 1919 m. sausio 12 d., LCVA, f. 383, ap.7, b. 52, 1. 16-17; Krašto apsaugos ministro ịsakymas, 1919 m. vasario 4 d., LCVA, f. 383, ap. 7, b. $52,1.20$. 
tūros kuopa, atvirkščiai, jai liko ištikima ${ }^{21}$. Tai rodo, kad kariuomenès daliniai pagal jiems vadovaujančių karininkų politines pažiūras suskilo: 2-ojo pèstininkų pulko vadas plk. ltn. V. Grigaliūnas-Glovackis atsisakè vykdyti krašto apsaugos ministro įsakymus, o kpt. K. Škirpa ir jo vadovaujama karo komendantūra liko ištikima vyriausybei. Susiklosčiusi situacija turèjo ịtakos Ypatingųjų valstybès įstatų nuostatų, prieštaraujančių Laikinosios Konstitucijos nustatytam kariuomenès teisiniam pavaldumui, paskelbimui, kadangi tai stiprino vyriausybès pozicijas ir turejo priversti jai paklusti 2-ojo pėstininkų pulko vadą. Reaguodama ị jo nepaklusnumą vyriausybei, savavališką elgesị paskiriant Marijampolès karo komendantą kpt. Joną Motiejūną-Valevičių ir karo padètį ${ }^{22}, 1919$ m. vasario 15 ir $16 \mathrm{~d}$. vyriausybè paskelbè Ypatinguosius valstybės apsaugos i̊status ir İstojimo ị Lietuvos krašto apsaugą sąlygas, kuriose prisiskyrè sau teisę valdyti kariuomenę, kadangi šiuose teisès aktuose teigiama, kad krašto apsauga yra vyriausybès žinioje ${ }^{23}$, o teisę skelbti „karo stovị turi Ministrų Kabinetas “24. Faktiškai tai reiškè, kad karo komendantas yra pavaldus krašto apsaugos ministruii ${ }^{25}$ Tą pačią dieną Ministrų Kabinetas paskelbė karo padètị Seinų, Vilkaviškio, Marijampolès, Alytaus ir Kauno miestuose ir paskyrė karo komendantus. ${ }^{26}$ Vyriausybės paskelbti teisès aktai prieštaravo Laikinajai Konstitucijai, todèl Tarybos prezidiumas ju nepripažino ir M. Sleževičiaus vadovaujama vyriausybè, palaikiusi tai nepasitikèjimu, buvo priversta atsistatydinti.

$1919 \mathrm{~m}$. kovo $5 \mathrm{~d}$. Valstybès Taryba paskelbè Ypatinguosius valstybès apsaugos įstatus, kuriuose nurodè, kad karo padèti skelbia ir panaikina Valstybès Tarybos prezidiumas, o karo metu armijai - vyriausiasis karo

21 Kęstutis Kilinskas, Pulkininkas prieš vyriausybę: plk. V. Girgaliūno-Glovackio ir Mykolo Sleževičiaus vyriausybių santykiai 1919 ir 1926 m., Acta historica universitatis Klaipedensis, t. XXXII, 2016, p. 79-96.

22 V. Grigaliūno-Glovackio apkaltinamasis raštas, 1919 m. balandžio 21 d., LCVA, f. 929, ap. 1, b. 3, 1. 4-9.

23 İstojimo ị Lietuvos krašto apsaugą sąlygos, 1919 m. vasario 16 d., LCVA, f. 383, ap. 7, b. $52,1.39-41$.

24 Ypatingieji valstybès apsaugos įstatai, 1919 m. vasario 15 d., LCVA, f. 383, ap. 7, b. 52, 1. 36-38.

25 Modestas Kuodys, Pirmasis Lietuvos kariuomenès karo komendantų suvažiavimas (1921 m. rugsèjo 21-24 d.), Karo archyvas, t. 26, 2011, p. 82.

26 Ten pat, 1. 39. 
$\operatorname{vadas}^{27}$. Naujai buvo paskelbtos ir Sąlygos stoti i Lietuvos krašto apsaugą bei nurodyta, kad ši įstatymą skelbia Valstybès Tarybos prezidiumas ${ }^{28}$. Paskelbdama naujuosius teisès aktus, Valstybès Taryba susigrąžino 1918 m. lapkričio 2 d. Laikinosios Konstitucijos pamatiniuose désniuose nustatytą kariuomenès pavaldumą. Tačiau šiuos pasikeitimus lėmè tarp dešiniųjų ir kairiųjų politinių sluoksnių atsiradusi trintis, kadangi Valstybès Taryba, kurioje dominavo kairieji, siekè apriboti socialistų liaudininkų vyriausybės galias ${ }^{29}$. Didelę reikšmę šiems įvykiams turèjo 2-ojo pėstininkų pulko vado karininko Vinco Grigaliūno-Glovackio atsisakymas paklusti M. Sleževičiaus vyriausybei, jo palankumas Valstybės Tarybai ir vyriausybès siekis suvaldyti nepaklusnųji pulko vadą ${ }^{30}$. Taigi, jau pirmaisiais valstybės kūrimo mėnesiais teisinis kariuomenès vadovybès pavaldumo politinei valdžiai klausimas tapo Tarybos ir vyriausybės politinès konkurencijos ịkaitu ir priklausė nuo jų politinès galios.

Po pirmaisiais valstybès kūrimosi mènesiais kilusio konflikto dèl kariuomenès vadovybès pavaldumo politinei valdžiai $1919 \mathrm{~m}$. balandžio 4 d. buvo pakoreguoti Laikinosios Konstitucijos pamatiniai dėsniai. Panaikinus Tarybos prezidiumą, ịsteigtas Respublikos Prezidento institutas, kuriam pagal kompetenciją buvo priskirta Lietuvos kariuomenė ir teisė skirti vyriausiąji karo vadą ir aukštesniuosius kariuomenès valdininkus ${ }^{31}$. Subordinuojant kariuomenès vadovybę Respublikos Prezidentui buvo siekiama didesnio stabilumo, kadangi galvota, kad, keičiantis Ministrų Kabinetui, keisis ir kariuomenès vadovybè, todèl bandyta to išvengti ${ }^{32}$. Praktiškai susiklostė situacija, kad Respublikos Prezidento aktai ir įsakymai kariuomenei turèjo būti pasirašomi ministro pirmininko ir krašto apsau-

\footnotetext{
27 Ypatingieji valstybès apsaugos įstatai, Laikinosios vyriausybès žinios, $1919 \mathrm{~m}$. balandžio 4 d., 1. 2.

28 Sąlygos stoti ị Lietuvos krašto apsaugą, Laikinosios vyriausybès žinios, 1919 m. balandžio 4 d., 1. 3.

29 Modestas Kuodys, Karo padeties režimas Lietuvos Respublikoje 1919-1940 m., daktaro disertacija, Kaunas, 2008, p. 31-32.

30 Česlovas Laurinavičius, M. Sleževičiaus kabineto krizè, Lietuvos Nepriklausomybè, t. X, d. 1, sud. Danutė Blaužytė-Baužienè, Edmundas Gimžauskas, Česlovas Laurinavičius, Dangiras Mačiulis, Gediminas Rudis, Artūras Svarauskas, Jonas Vaičenonis, Vilnius, 2013, p. 144-145.

31 Kazimieras Valančius, Lietuvos valstybès konstitucijos, Vilnius, 1989, p. 7-13.

32 Valstybès Taryba, XIV sesija, 3 posèdis, Laisve, 1919 m. balandžio 6 d., p. 1.
} 
gos ministro. Dèl šios vadovavimo kariuomenei tvarkos nepaisymo kilo keletas konfliktų tarp prezidento, ministro pirmininko ir krašto apsaugos ministro. 1919 m. liepos 6 d. sutiekiant karūžo laipsnị Karo mokyklos I laidos absolventams, buvo perskaitytas vyriausiojo karo vado S. Žukausko ìsakymas, nepasirašytas nei ministro pirmininko, nei Respublikos Prezidento $^{33}$. Ši îsakymą A. Smetona pasirašè „post factum“, tačiau M. Sleževičius tai laikè neteisètu veiksmu, kadangi tuo metu dar nebuvo parengtas ir priimtas ịstatymas dèl karinių laipsnių teikimo ${ }^{34}$. Vèliau, 1919 m. spalio mèn., Respublikos Prezidento aktu be ministro pirmininko ir krašto apsaugos ministro parašų gen. Silvestras Žukauskas buvo apdovanotas dviem Vyčio Kryžiaus ordinais ir atleistas iš pareigų, o vietoj jo naujuoju vyriausiuoju karo vadu paskirtas karininkas Pranas Liatukas ${ }^{35}$. Ministras pirmininkas M. Sleževičius šiuos prezidento veiksmus laike prieštaraujančiais Laikinųjų Konstitucijos dèsnių vienuoliktajam paragrafui, kuriame teigiama, kad visi Respublikos Prezidento skelbiami aktai turi būti pasirašyti ministro pirmininko arba atitinkamo ministro ${ }^{36}$. Santykiai su Respublikos Prezidentu dèl kariuomenès valdymo teisètumo tapo viena iš M. Sleževičiaus vadovaujamos ketvirtosios vyriausybės atsistatydinimo priežasčių. 1919 m. rugsèjo 26 d. keturi su Pažangos partija susiję ministrai įteikè M. Sleževičiui atsistatydinimo pareiškimą, kuriame vyriausybès politiką ịvardijo kaip „partijų varžymąsi dèl armijos ir vyriausiojo karo

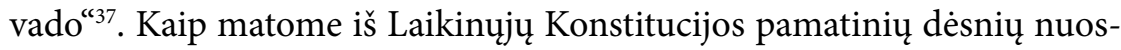
tatų, nustatytas kariuomenès valdymas buvo nepakankamas ir sudarè prielaidas politinèms jègoms tuo naudotis tarpusavio kovoje.

Reikia pasakyti, jog M. Sleževičius dejjo pastangas, kad sureguliuotų Lietuvos prezidento, ministro pirmininko ir karinès vadovybès santykius. 1919 m. jam vadovaujant vyriausybei, buvo parengtas trumpas İstatymo

33 Feliksas Žigaras, Generolas Jonas Galvydis-Bykauskas ir pirmosios Karo mokyklos laidos, ats. red. A. Alonderis, Generolas Jonas Galvydis-Bykauskas 1864-1843, Vilnius, 2014, p. 139.

34 Ministrų kabineto protokolas, 1919 m. liepos 11 d., LCVA, f. 923, ap. 1, b. 97, 1. 24.

35 Ministro pirmininko akto nuorašas, 1919 m. spalio 7 d., LCVA, f. 923, ap. 1, b. 58, 1. 169.

36 Kazimieras Valančius, Lietuvos valstybès konstitucijos, Vilnius, 1989, p. 10.

37 Raštas Ministrui Pirmininkui, 1919 m. rugsèjo 26 d., LCVA, f. 923, ap. 1, b. 11, 1. 34-35. 
apie Lietuvos kariuomenès organizaciją projektas, tačiau mums nepavyko rasti duomenų, rodančių, kad šis įstatymas buvo svarstytas arba priimtas. Istatymo pirmajame paragrafe numatyta, kad Lietuvos kariuomenès karių skaičių taikos metu nustato Seimas, o karo metu - vyriausybe ir armijos vadas ir tvirtina Respublikos Prezidentas ${ }^{38}$. Panašaus pobūdžio, tačiau labai lakoniškas įstatymas vis dèlto buvo priimtas 1920 m. gegužès 7 d. Respublikos Prezidento įsakymu. Juo buvo atskirtos vyriausiojo karo vado ir krašto apsaugos ministro kompetencijos. Vyriausiajam karo vadui buvo pavestas kariuomenès rikiuotès ir operacijų valdymas, o krašto apsaugos ministro kompetencijai priklausè visas tiekimas, sanitarija, veterinarija, teismas, mobilizacija ir vietinè kariuomene $\dot{~}^{39}$. Tai rodo, kad, pasibaigus vyriausybès ir Tarybos konfliktui, vis dèlto buvo siekiama sureguliuoti karinès ir politinès vadovybès santykius, o Nepriklausomybės kovų metu vykę konfliktai inspiravo mėginimus apibrèžti karo vadų pavaldumą politinei valdžiai.

\section{BEVAISĖS PASTANGOS DEMOKRATIZUOTI KARIUOMENĖS VALDYMA}

1920 m. birželio 12 d. Steigiamasis Seimas paskelbẻ Trečiąją laikinąją Lietuvos Valstybės Konstituciją, kurios aštuntas paragrafas numatė, kad aukštesniuosius kariuomenès ir valstybès valdininkus skiria Respublikos Prezidentas $^{40}$. Ši Konstitucija ir gegužès 7 d. išleistas Respublikos Prezidento įsakymas karinès ir politinès vadovybès santykių nesureguliavo. 1920 m. birželio mėn. vykusiame kariuomenès dalinių vadų suvažiavime, kuriame dalyvavo kariuomenès dalinių vadai ir politinių partijų atstovai, plk. ltn. Vincas Grigaliūnas-Glovackis ir plk. ltn. Kazys Ladyga konstatavo, kad skaitant Konstituciją „neaišku, kam priklauso kariuomené “41. Po šio suvažiavimo, $1920 \mathrm{~m}$. liepą, prasidèjo beveik pusantrų metų trukęs Ginkluotųjų pajègų ir jų įstaigų valdymo įstatymo, kurio svarbiausios

\footnotetext{
38 İstatymo apie Lietuvos kariuomenès organizaciją projektas, 1919 m., LCVA, f. 923, ap. 1 , b. $58,1.46-47$.

39 Issakymas Lietuvos kariuomenei, 1920 m. gegužès 7 d., LCVA, f. 929, ap. 5, b. 407, 1. 5.

40 Kazimieras Valančius, Lietuvos valstybès konstitucijos, Vilnius, 1989, p. 7.

41 Karo vadų suvažiavimo protokolai, LCVA, f. 384, ap. 2, b. 87, 1. 50.
} 
nuostatos buvo parengtos posėdžiaujant karinių dalinių vadams, rengimas. Posėdžiuose dalyvavo ir įstatymo projektą rengė svarbiausieji kariuomenès pareigūnai: krašto apsaugos ministras plk. ltn. Konstantinas Žukas, Generalinio štabo viršininkas gen. ltn. Stasys Nastopka, II divizijos vadas, gen. štabo viršininkas gen. Maksimas Katche, I divizijos vadas plk. ltn. Kazys Ladyga, Vietinès kariuomenès brigados vadas gen. ltn. Jurgis Kubilius, Susisiekimo, Artilerijos ir Tiekimo skyrių viršininkai ${ }^{42}$.

Svarbiausiais buvo laikomi kariuomenès vadovybės, jos vado ir krašto apsaugos ministro santykių sureguliavimo, jų teisių ir pareigų nustatymo klausimai. Per posèdžius buvo vienbalsiai nutarta, kad vyriausioji kariuomenės vadovybè turi būti vienose rankose - krašto apsaugos ministro ${ }^{43}$. Diskusijų metu buvo siūlomi du kariuomenès subordinavimo politinei valdžiai variantai: plk. ltn. Kazys Ladyga pasiūlè, kad krašto apsaugos ministras būtų tiesiogiai pavaldus Respublikos Prezidentui ${ }^{44}$, o dauguma Karo tarybos narių, tarp jų ir plk. ltn. Konstantinas Žukas, gen. ltn. Maksimas Katche, plk. Stasys Zaskevičius, - kad ministras priklausytų nuo suverenios valdžios, t. y. būtų skiriamas ministro pirmininko ${ }^{45}$. Dar viena rimta problema, su kuria teko susidurti ịstatymo rengejjams, buvo Tiekimo skyriaus pavaldumo klausimas. Plk. ltn. K. Ladyga teigè, kad Tiekimo skyrius, kaip Operacijų ir Rikiuotès skyriai, turètų būti pavaldus armijos vadui ${ }^{46}$. O plk. ltn. K. Žukas ir gen. ltn. Stasys Nastopka siūlè Tiekimo skyrių palikti krašto apsaugos ministro žinioje, motyvuodami tuo, kad tiekimo sritis nebepriklausanti karo vado kompetencijai ${ }^{47}$. Kaip matysime vèliau, ši problema parengtame įstatymo projekte buvo išspręsta Tiekimo skyriaus pavaldumo sritis paskirstant tarp krašto apsaugos ministro ir kariuomenès vado. Sanitarijos, Veterinarijos ir Kariuomenès intendantūros skyriai buvo priskirti krašto apsaugos ministro kompetencijai, tačiau drausmès ir rikiuotès klausimais - kariuomenès vadui ${ }^{48}$.

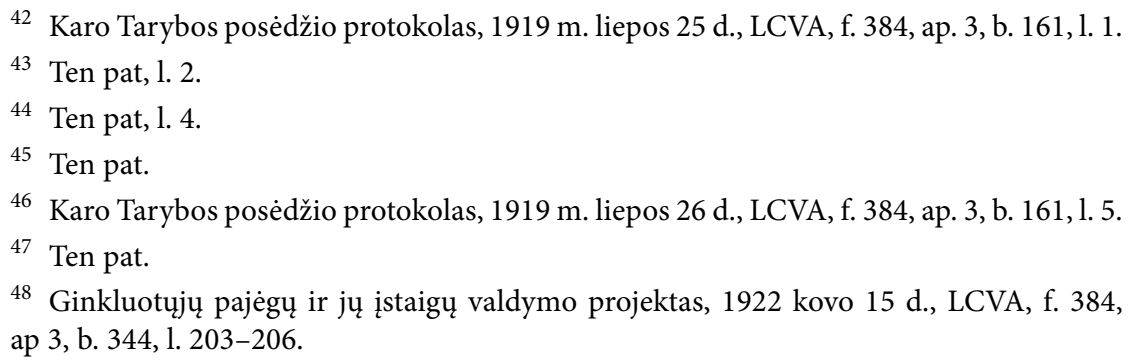


Rengiant ši įstatymo projektą buvo remtasi 1869 m. carinès Rusijos imperijos kariuomenès įstatymų sąvadu. Tai rodo ne tik karininkų diskusijos, bet ir tai, kad 1921 m. gegužès mènesị Krašto apsaugos ministerijos Literatūros skyriaus viršininkui ịsakoma iš rusų kalbos išversti Rusijos imperijos Ginkluotųjų pajègų ir jų ịstaigų valdymo ịstatymą ${ }^{49}$. Istatymų rengejai taip pat domèjosi Vakarų valstybių patirtimi. $1921 \mathrm{~m}$. sausio mèn. Krašto apsaugos ministerijos projektų komisija krašto apsaugos ministro padejejui pristatė Danijos karo ministerijos organizavimo schemą ir aukštųjų valdymo organų organizacijos paaiškinimus, kurie turëjo „pasitarnauti kaip medžiaga išdirbant projektus ir dèsnius atitinkamų isstaigų Lietuvoje “50. Karinejje spaudoje buvo apžvelgtos didžiausių Vakarų valstybių - Jungtinių Amerikos Valstijų, Prancūzijos, Anglijos, Vokietijos, Italijos - ir Rusijos aukštųjų kariuomenès vadovybių struktūros ir jų pokyčiai po Pirmojo pasaulinio karo. Buvo pabrèžiama, kad po Pirmojo pasaulinio karo daugelis Vakarų valstybių pasuko kariuomenės valdymo demokratizavimo keliu, ir kaip svarbiausi šio proceso požymiai nurodyti civilio, einančio krašto apsaugos ministro pareigas vyriausybejje, skyrimo ir kolegialaus organo, Karo Tarybos, sprendžiančio karo reikalus, formavimo principai pabrèžiant, kad iki Pirmojo pasaulinio karo vadovybès priešakyje stovejjo karo vadas, dažniausiai generolas, pavaldus tik valstybès galvai ${ }^{51}$. O po karo svarbiausieji reikalai buvo sprendžiami demokratiškai išrinktos politinès valdžios krašto apsaugos ministro ir Karo Tarybos, sudarytos iš svarbiausių civilių ir karinių valstybès pareigūnų ${ }^{52}$.

Iš šių straipsnių galime susidaryti ịspūdị, kad kariuomenès valdymo demokratizavimas reiškè platesni valstybès vykdomosios valdžios ittraukimą ị karo reikalų svarstymą ir sprendimų prièmimą. Kai kuriuose straipsniuose spaudoje teigta, kad Lietuvos kariuomenei dèl itin komplikuotos padèties, kai Krašto apsaugos ministerijai tenka valdyti kreditus, pirkti arba rekvizuoti karo reikmenis, visiškai netinka buvusios carinès Rusijos imperijos kariuomenès aprūpinimo būdas, o kartu ir jos orga-

\footnotetext{
49 Isakymas Literatūros skyriaus viršininkui, $1921 \mathrm{~m}$. gegužès 7 d.

50 Raportas krašto apsaugos ministro padejejejui, 1920 m. spalio 21 d., LCVA, f. 384, ap. 3, b. $344,1.134$.

51 Leonas Radus-Zenkavičius, Aukštesnioji karo vadovybė buvo Didžiojo karo, Karys, nr. 31, 1921 rugpjūčio 4 d., 1.1 .

52 Aukštesnioji karo vadovybè buvo Didžiojo karo, Karys, nr. 43, 1921 spalio 27 d., 1. 5.
} 
nizacija bei valdymas, atsižvelgiant ị Lietuvos kariuomenès ypatybes ir struktūrą ${ }^{53}$.

$1921 \mathrm{~m}$. antrojoje pusejje čia jau ịvardinti asmenys parengè Ginkluotụjų pajègų ir jų ịstaigų valdymo įstatymo, kuriame buvo numatyta, kad Lietuvos Respublikos kariuomenès ir jos įstaigų viršininkas yra krašto apsaugos ministras, o jam pavaldžios visos Krašto apsaugos ministerijos ìstaigos, projektą. Karo metu kariuomenei vadovauti skiriamas kariuomenès vadas, kurị iki karo pavaduoja Kariuomenès štabo viršininkas. Kariuomenès vadą, Ministrų Kabinetui pristačius, skiria ir atleidžia Respublikos Prezidentas ${ }^{54}$. Šios ịstatymo nuostatos aiškiai nurode kariuomenès pavaldumą demokratiškai išrinktai politinei valdžiai ir atskyrè politines ir karines valdžios institucijas, kariuomenès vadui suteikdamos savarankiškumą ir teisę valdyti kariuomenę, užtikrino jo savarankiškumą operatyvinèje srityje ir atskaitomybę Ministrų Kabinetui ${ }^{55}$. Politinei valdžiai buvo apribota teisė kištis ị karinius reikalus: Ministrų Kabinetas kariuomenès vadui galejjo duoti tik bendrus nurodymus ir direktyvas krašto gynimo reikalais ${ }^{56}$. Krašto apsaugos ministrui buvo suteikta priežiūros ir kontrolès funkcija, jis turejjo skelbti ir vykdyti Ministrų Kabineto nutarimus visais ginkluotųjų pajègų klausimais ir svarbesniąsias kariuomenès ùkio ir maitinimo operacijas, jo žinioje taip pat buvo visų karo žinybos šakų centrinè kontrolè ir tiekimas. Kariuomenès dalinių formavimo ir steigimo teisè buvo suteikta Ministrų Kabinetui, kuris kariuomenès vado ir krašto apsaugos ministro prašymu leidžia steigti kariuomenès dalinius. Prie krašto apsaugos ministro turejjo būti ịsteigta Karo taryba. Pagal ši įstatymą, visus karius ị kariuomenę priima ir atleidžia krašto apsaugos ministras, išskyrus tuos, kurių priemimo teisè priklauso Respublikos Prezidentui. Karo veiksmų zonoje kariuomenès vado ịsakymus vykdo karo ir kitų Respublikos ir visuomenès įstaigų valdininkai ir gyventojai ${ }^{57}$.

\footnotetext{
53 Lietuvos kariuomenès tiekimų organizacijos klausimu, Mūsų žinynas, nr. 1, 1921, p. 124-129.

54 Ginkluotųjų pajègų ir jų ịstaigų valdymo įstatymo projektas, $1922 \mathrm{~m}$. kovas, LCVA, f. 929 , ap. 1, b. $422,1.13-18$.

55 Ten pat.

56 Ten pat.

57 Ginkluotųjų pajègų ir jų įstaigų valdymo įstatymo projektas, $1922 \mathrm{~m}$. kovas, LCVA, f. 929 , ap. 1, b. $422,1.13-18$.
} 
Reikia pasakyti, kad 1920-1921 m. rengtas Ginkluotųų pajègų ir jų i̇staigų valdymo įstatymas pasižymėjo aiškiomis demokratinėmis tendencijomis, ginkluotųjų pajėgų valdymas buvo išskaidytas tarp demokratiškai išrinktų valstybės valdymo institucijų, Prezidento, Ministrų Kabineto ir kariuomenès vadų, o prie krašto apsaugos ministro buvo įsteigta iš civilių ir karinių pareigūnų sudaryta Karo taryba.

$1922 \mathrm{~m}$. sausio $27 \mathrm{~d}$. šio įstatymo projektas buvo ịtrauktas ị Steigiamojo Seimo posėžio darbotvarkę, tačiau, kaip rodo Steigiamojo Seimo posėdžių stenogramos, tądien jis nebuvo svarstytas ${ }^{58}$. Toks pat likimas ji ištiko ir sausio $31 \mathrm{~d}$., tik vasario $1 \mathrm{~d}$. ịstatymas buvo apsvarstytas už uždarų durų ${ }^{59}$. Kadangi šio posėdžio stenogramos neišliko, neįmanoma pasakyti, kaip vyko šio i̇statymo svarstymas, tačiau panašu, kad jis po Steigiamojo Seimo posėdžio buvo grąžintas patikslinti, kadangi mūsų rastoje $1922 \mathrm{~m}$. kovo $15 \mathrm{~d}$. įstatymo versijoje pastebejome tik vieną pataisą - kad karinių dalinių vadus, pradedant nuo atskirojo bataliono vado, brigados vado teikimu skiria Respublikos Prezidentas ${ }^{60}$. Daugiau Ginkluotụjų pajėgų ir jų ịstaigų valdymo ịstatymas Seime niekada nebuvo svarstytas ir priimtas, todèl visą demokratinès valstybès egzistavimo laikotarpi kariuomenès valdymas buvo sureguliuotas tik $1922 \mathrm{~m}$. Konstitucijos nuostatomis, kurios numate, kad Respublikos Prezidentas yra vyriausiasis visų ginkluotųjų pajėgų viršininkas. Už „Respublikos Ginkluotųjų pajėgų valdymą, tvarkymą ir vadovavimą joms atsako Seimui Ministrų kabinetas ar atitinkamas ministras. Karo metu ministrų kabinetui pasiūlius, Respublikos prezidentas skiria vyriausiąji kariuomenès vadą “61. Taigi matome, kad Konstitucija tik bendro pobūdžio nuostatomis, nedetalizuodama Prezidento, vyriausybès, Krašto apsaugos ministerijos ir karo vadų pareigų, apibrèžè kariuomenès valdymo schemą. Dèl šio Konstitucijos straipsnio kilusios diskusijos leidžia susidaryti ịspūdị, kokios nuomonès apie kariuomenès pavaldumą laikèsi politinès partijos. $1922 \mathrm{~m}$. balandžio $10 \mathrm{~d}$. Seimo narys krikščionis demokratas Elizejjus Draugelis

\footnotetext{
581922 m. sausio 27 d. 164 posèdžio stenograma, Steigiamojo Seimo darbai (nuo sausio 24 iki vasario $3 d$. ), p. 38.

591922 m. vasario 1 d. posėdžio stenograma, Steigiamojo Seimo darbai, p. 83-84.

60 Ginkluotụjų pajègų ir jų isstaigų valdymo įstatymo projektas, $1922 \mathrm{~m}$. kovo $15 \mathrm{~d}$., LCVA, f. 384, ap. 3, b. 344, 1. 204-206.

61 Kazimieras Valančius, Lietuvos valstybès konstitucijos, Vilnius, 1989, p. 7-13.
} 
pasiūlè pavesti ginkluotųjų pajėgų valdymą vienam asmeniui - Prezidentui, motyvuodamas tuo, kad „ginkluotosios pajègos būtų tik respublikos, tik valstybès, o ne kokios partijos žinioje“, tačiau tik tokiu atveju, jeigu išrinktasis Prezidentas išeis iš partijos ir prisieks Konstitucijai ${ }^{62}$. E. Draugelio poziciją palaikè ir krikdemas Vytautas Bičiūnas, kurio nuomone, Prezidentas būtų tas asmuo, kuris turètų „daug didesnès ịtakos ir daug didesnès svarbos" kariuomeneje nei bet kas kitas ${ }^{63}$. Daugelis kairiụjų partijų atstovų prieštaravo kariuomenès pavaldumui Prezidentui. Žinoma, socialdemokratai prieštaravo ir pačios Prezidento institucijos egzistavimui. Socialdemokratų partijos vardu kalbejo socialdemokratas Vladas Požèla ${ }^{64}$ ir jo bendrapartietis Vincas Čepinskis, kurie gynè nuomonę, kad Prezidentas būtų nepartinis, yra neịmanoma, todèl teisę vadovauti kariuomenei reikia suteikti Ministrų Kabinetui, o ne vienam asmeniui ${ }^{65}$. Jam antrino ir valstietis liaudininkas Pranas Ruseckas, pasak kurio, net ir „karo metu kariuomenès priklausymas vienam asmeniui neišsprendè dèl to kilusių problemų"66. Galiausiai, atsižvelgęs ị Konstitucijos komisijos ir krikščionių demokratų bloko siūlymą bei kairiųjų partijų prieštaravimą Prezidento institucijai, Steigiamasis Seimas nutarè, kad kariuomenè bus vyriausybės žinioje ${ }^{67}$. Galutinè $1922 \mathrm{~m}$. Konstitucijos formuluote, kuria apibūdinamas ginkluotųjų pajègų valdymas, skamba taip: „Respublikos Prezidentas yra vyriausiasis visų ginkluotųjų pajègų viršininkas. Už Respublikos Ginkluotųų pajėgų valdymą, tvarkymą ir vadovavimą joms atsako Seimui Ministrų kabinetas ar atitinkamas ministras. Karo metu, Ministrų kabinetui pasiūlius, Respublikos prezidentas skiria vyriausiąji kariuomenès vadą. “68 Taip Lietuvos Konstitucijoje buvo įtvirtintos demokratinès kariuomenès valdymo nuostatos.

\footnotetext{
62 Steigiamojo Seimo stenogramos, 1922 balandžio 10 d. posėdis, p. 110.

63 Ten pat, p. 110-113.

641922 m. liepos 18 d. posèdžio stenograma, Steigiamojo Seimo darbai, 46 sąsiuvinis, 1922, p. 110-11.1

65 Steigiamojo Seimo stenogramos, 1922 balandžio 10 d. posèdis, p. 110-113.

661922 m. liepos 18 d. posėdžio stenograma, Steigiamojo Seimo darbai, 46 sąsiuvinis, 1922, p. 114-115.

67 Steigiamojo Seimo stenogramos, 1922 balandžio 10 d. posėdis, p. 124.

68 Kazimieras Valančius, Lietuvos valstybès konstitucijos, Vilnius, 1989, p. 7-13.
} 
Karinės vadovybės nuomone, Konstitucijoje numatytas ginkluotujų pajègų pavaldumas politinei valdžiai neišsprendè Krašto apsaugos ministerijos ir aukštosios kariuomenès vadovybès tarpusavio santykių problemos. Štai 1922 m. pabaigoje Generalinio štabo viršininkas gen. ltn. M. Katche skundèsi krašto apsaugos ministrui, kad vadovavimo kariuomenei pamatas per silpnas, jo nuomone, nèra aiškiai apibrěžtos krašto apsaugos ministro ir pirmojo ministro pavaduotojo rikiuotès srityje - kariuomenès vado veikimo ribos, taip pat neaiškus Generalinio štabo viršininko pavaldumas: esą neaišku, kas jam duoda įsakymus - krašto apsaugos ministras, jo padèjèjas ar kariuomenès vadas, todèl reikalavo, kad būtų kuo greičiau ir tiksliau apibrèžtos krašto apsaugos ministro teisès ir pareigos ${ }^{69}$. Veikiausiai dèl to aukštoji karininkija ir toliau stengèsi išspręsti šią problemą.

1924 m. kariuomenès vadovybès karo metu sutvarkymo projektą ėmèsi rengti gen. Leonas Radus-Zenkavičius. Jo parengtame ịstatymo projekte teigiama, kad Krašto apsaugos ministerija yra vyriausioji kariuomenès vadovavimo ir valdymo įstaiga. Ministerijai vadovauja krašto apsaugos ministras, kuris turi teisę po Respublikos Prezidento skelbti įsakymus kariuomenei. Kariuomenès vadas yra didžiausias viršininkas kariuomenès drausmès ir rengimosi karui klausimais. Kariuomenès vadui pavaldūs Vyriausiojo štabo, artilerijos, aviacijos, karo apygardų ir karo technikos viršininkai ir šaudymo inspektorius. Krašto apsaugos ministrui priklauso ūkio, finansų valdybos ir Kariuomenès teismas ${ }^{70}$.

Tačiau šis įstatymas taip ir liko Kariuomenès vyriausiojo štabo kabineto stalčiuose ir net nebuvo pradètas svarstyti. Neturint jokio politinès valdžios priimto krašto apsaugos institucijų valdymą reguliuojančio įstatymo susidarė prielaidos karinei vadovybei keisti ginkluotųjų pajėgų valdymo struktūrą pagal konkrečiu laiku kariuomenei vadovaujančių asmenų nuostatas, pažiūras ir norus. Štai 1926 m. tuometis Vyriausiojo štabo viršininkas gen. ltn. K. Ladyga išplètė Vyriausiojo štabo viršininko galias, skirdamas jam vadovauti kariuomenès dalims ir suteikdamas teisę duoti nurodymus Tiekimų valdybai ir Kariuomenès teismui ${ }^{71}$. Reikètų pasakyti,

69 Generalinio štabo viršininko pareiškimas, 1922 m. lapkričio 20 d., LCVA, f. 384, ap. 3, b. 344, 1. 134-135.

70 Generalinio štabo I skyriaus viršininko raporto priedas Nr. 4, 1934 m. liepos 9 d., LCVA, f. 929, ap. 5, b. 407, 1. 9.

71 Generalinio štabo I skyriaus viršininko raporto priedas Nr. 5, 1934 m. liepos 9 d., LCVA, f. 929, ap. 5, b. 407, 1. 10. 
kad 1920 m. liepos mèn., svarstant Tiekimų skyriaus pavaldumo klausimą, rengiant Ginkluotųjų pajègų ir jų įstaigų valdymo įstatymą, gen. ltn. K. Ladyga pasiūlè, kad kariuomenès Tiekimų valdyba būtų pavaldi kariuomenès vadui, o tapęs Vyriausiojo štabo viršininku savo sumanymą igyvendino. Keletą pataisų gen. K. Ladygos parengtoje schemoje padarè plk. Kazys Škirpa, 1926 m. kariuomenès vado institutą pavertęs kariuomenès vyr. inspektoriaus pareigybe, o kariuomenès dalinius - tiesiogiai pavaldžiais Vyriausiojo štabo viršininkui ${ }^{72}$. Reikia pasakyti, kad plk. K. Škirpa savo vizijose ir reformų planuose kariuomenès vyr. inspektoriui numate svarbų vaidmenị: jis turejjo būti pavaldus krašto apsaugos ministrui, o kilus karui - skiriamas vyriausiuoju karo vadu. Taikos metu kariuomenès vyr. inspektorius turejo parengti „ginkluotąsias pajègas laimèjimui karo metu“, taigi tai turèjo būti žmogus, atsakingas už kariuomenès parengimą ir šiuo klausimu likti savarankiškas, o biudžetiniai ir politiniai klausimai turèjo priklausyti krašto apsaugos ministro kompetencijai ${ }^{73}$.

Tokia kariuomenès valdymo schema egzistavo iki 1927 m., kol po valstybès perversmo Vyriausiojo štabo viršininkas ir vienas svarbiausių perversmo dalyvių plk. Povilas Plechavičius panaikino kariuomenès gen. inspektoriaus pareigybę, kad visa valdžia atsidurtų Vyriausiojo štabo viršininko rankose ${ }^{74}$. Nagrinėdami po $1926 \mathrm{~m}$. gruodžio $17 \mathrm{~d}$. perversmo kariuomenès valdymą reglamentuojančius valstybės teisès aktus ir jų projektus galime pastebèti ir daugiau perversmo organizatorių ir vykdytojų pastangų atiduoti kariuomenès valdymą i jų rankas. Tokių požymių pirmiausia yra Lietuvos Respublikos Konstitucijoje, kurioje Respublikos Prezidentui Antanui Smetonai suteikiama teisè skirti ir atleisti iš tarnybos visų laipsnių karininkus ir valdininkus pagal įstatymą ${ }^{75}$. Tai reiškia, kad be Respublikos Prezidento žinios ị tarnybą kariuomenëje negalëjo būti paskirtas nè vienas karininkas. Tais pačiais metais parengtame Ginkluotųjų pajègų taikos metu valdymo ịstatymo projekte yra nuosta-

\footnotetext{
72 Generalinio štabo I skyriaus viršininko raporto priedas Nr. 6, 1934 m. liepos 9 d., LCVA, f. 929, ap. 5, b. 407, 1. 11.

73 Jonas Vaičenonis, Lietuvos kariuomenès vyriausiojo štabo viršininko plk. Kazio Škirpos Lietuvos kariuomenès vystymo planas, Karo archyvas, 2006, nr. 21, p. 351-352.

74 Generalinio štabo I skyriaus viršininko raporto priedas Nr. 7, $1934 \mathrm{~m}$. liepos 9 d., LCVA, f. 929, ap. 5, b. 407, 1. 12.

75 Kazimieras Valančius, Lietuvos valstybes konstitucijos, Vilnius, 1989, p. 48.
} 
ta, ịpareigojanti (ne suteikianti teisę) krašto apsaugos ministrą atstovauti ginkluotųjų pajègų reikalams pas Respublikos Prezidentą, Seime, Vyriausybeje, teisme ir visuomenej $\mathrm{e}^{76}$. Tai reiškia, kad Konstitucijos nuostatomis ir vyr. inspektoriaus pareigybės panaikinimu buvo siekiama suformuoti aiškią Respublikos Prezidento, ministro ir Vyriausiojo štabo viršininko pavaldumo grandinę, kai kariuomenė paklūsta svarbiausiems $1926 \mathrm{~m}$. gruodžio $17 \mathrm{~d}$. perversme dalyvavusiems asmenims - Antanui Smetonai, Antanui Merkiui ir plk. P. Plechavičiui. Šioje vadovavimo grandinejje galime užčiuopti akivaizdžias autoritarinio režimo tendencijas.

\section{M. KARIUOMENĖS VADOVYBĖS İSTATYMAS: „PREZIDENTO VALIA - TAI VISKAS“}

Gen. Itn. Petro Kubiliūno veikla taip pat patvirtina mūsų jau ịvardytą tendenciją. $1930 \mathrm{~m}$. jis vèl įsteigè $1927 \mathrm{~m}$. panaikintą gen. inspektoriaus institutą, o $1931 \mathrm{~m}$. pradejo rengti ir aukštesnès karo vadovybès įstatymų projektą ${ }^{77} .1933$ m. ji i iteikè krašto apsaugos ministrui, siūlydamas apsvarstyti ir priimti $^{78}$. Šiame įstatyme akivaizdžiai išplečiamos Respublikos Prezidento ir Vyriausiojo štabo viršininko teisès, bet susiaurinama krašto apsaugos ministro atsakomybė. Istatymo projekto bendruosiuose dèsniuose teigiama, kad „Respublikos Prezidentas valdo kariuomenę per Krašto apsaugos ministrą ir Vyriausiojo štabo viršininką“. Respublikos Prezidentui suteikiama teisè skelbti mobilizaciją ir demobilizaciją, ìsakyti kariuomenei pradèti ir baigti karo veiksmus, tvirtinti valstybès saugumui sudaromas karo konvencijas, skirti pulko vado lygmens kariuomenès viršininkus, priimti karininkus ị karo tarnybą ir atleisti iš jos. Prezidentas taip pat turi aukščiausią kariuomenès priežiūros teisę ir vadovauja Valstybès gynimo tarybos posėdžiams ${ }^{79}$.

\footnotetext{
76 Ginkluotųjų pajègų valdymo taikos metu įstatymo projektas, 1928 m., LCVA, f. 929, ap. 5 , b. $259,1.4$.

77 Generalinio štabo I skyriaus viršininko raporto priedas Nr. 8, 1934 m. liepos 9 d., LCVA, f. 929, ap. 5, b. 407, 1. 13.

78 Vyriausiojo štabo viršininko kreipimasis, 1933 m. gegužès 23 d., LCVA, f. 929, ap. 5, b. $407,1.157$.

79 Istatymo aukštajai kariuomenès vadovybei projektas, 1933 m. gegužès 23 d., LCVA, f. 929 , ap. 5 , b. $407,1.158-160$.
} 
Šiuo ịstatymu A. Smetonai buvo užtikrinama teise, nepriklausomai nuo krašto apsaugos ministro, pradèti karo veiksmus, skelbti mobilizaciją, kontroliuoti skyrimo ị pareigas kariuomeneje klausimus ir t. t. O krašto apsaugos ministro vaidmuo atrodo gana formalus: jam paliekama teisé tvirtinti Vyriausiojo štabo viršininko ịsakymus, atstovauti kariuomenei Ministrų Tarybos posèdžiuose ir pas Respublikos Prezidentą ${ }^{80}$. Tuo pat metu Vyriausiojo štabo viršininko pareigos išplečiamos: jam priklauso ne tik kariuomenès rengimas karui - karo metu jis turi tapti vyriausiuoju karo vadu, jo kompetencijos sričiai taip pat priskiriamos kariuomenès mokymo ir drausmès priežiūros funkcijos, kurios $1922 \mathrm{~m}$. ìstatymo projekte buvo priskirtos krašto apsaugos ministro kompetencijai. Taigi, remdamasis šiuo įstatymo projektu, A. Smetona turejo užsitikrinti realią galią kontroliuoti kariuomenès pasirengimą karui, personalo skyrimą ir ginklavimą. Panašu, kad panašaus principo gen. ltn. P. Kubiliūnas laikèsi ir rengdamas tolesnius aukštosios karinès vadovybès ịstatymo projektus.

1934 m. žiemą parengtame Ginkluotųjų pajègų valdymo karo metu istatymo projekte įtvirtinta visiška kariuomenès vado priklausomybè nuo Respublikos Prezidento: kariuomenès vadas turejo būti skiriamas ir atleidžiamas Respublikos Prezidento, karo veiksmų metu - vadovautis Prezidento ịsakymais ir nurodymais, jokia kita įstaiga negalejjo duoti nurodymų ar įsakymų, susijusių su karo veiksmais. Respublikos Prezidento įsakymai turèjo būti kontrasignuojami kariuomenės vado, drausmès priežiūros srityje jam buvo suteiktos krašto apsaugos ministro teisès. Istatyme nebuvo nuostatų, kurios rodytų, kad kariuomenès vadas savo veiklą turi derinti su krašto apsaugos ministru. Jam netgi buvo suteikta teisė dalyvauti Ministrų Kabineto posėdžiuose, suteikus sprendžiamąji balsą svarstant kariuomenès reikalus.

Šis įstatymo projektas dar labiau susiaurino krašto apsaugos ministro kompetenciją, palikdamas jam tik administracines funkcijas. Ministras turejo rūpintis kariuomenès aprūpinimo organizavimu ir gamyba, palaikyti ryši su kariuomenès vadu ir visomis išgalèmis jam padėti ${ }^{81}$. Paskutiniame 1934 m. pavasarị plk. Jono Mačiulaičio ir gen. ltn. P. Kubiliūno parengtame įstatymo projekte iš esmès pakartojamos ankstesniojo projekto

\footnotetext{
80 Ten pat.

81 Ginkluotųjų pajègų valdymo karo metu įstatymo projektas, $1934 \mathrm{~m}$. žiema, LCVA, f. 929 , ap. 5, b. $407,1.215-219$.
} 
nuostatos, tik kariuomenès vado pareigos dar labiau išplečiamos krašto apsaugos ministro kompetencijos sąskaita, įtvirtinant nuostatą, kad kariuomenès vadas gali duoti įsakymus krašto apsaugos ministrui pavaldiems viršininkams ${ }^{82}$. Visuose gen. Itn. P. Kubiliūno vadovavimo Vyriausiajam štabui laikotarpiu parengtuose aukštesniosios karinès vadovybès isstatymuose akivaizdžiai linkstama visą vadovavimo galią sutelkti Respublikos Prezidento ir kariuomenès vado rankose, vis labiau apribojant krašto apsaugos ministro galias. Menkstantị krašto apsaugos ministro vaidmeni gen. ltn. P. Kubiliūno parengtuose kariuomenès valdymo projektuose būtų galima paaiškinti komplikuotais pastarojo santykiais su krašto apsaugos ministru plk. Baliu Giedraičiu. Lietuvos istoriografijoje įsitvirtinusi nuomonė, kad daugeli gen. ltn. P. Kubiliūno iniciatyvų ir sumanymų reorganizuoti ir reformuoti kariuomenę stabdè nesutarimai su krašto apsaugos ministru ir pasyvus pastarojo būdas ${ }^{83}$. Galbūt tai vertė generolą rengiant kariuomenès vadovybès veiklą reglamentuojančius istatymų projektus suteikti kuo mažiau galių krašto apsaugos ministrui ir taip savotiškai atsirevanšuoti. Tačiau minètasis ịstatymas nebuvo priimtas, o gen. ltn. P. Kubiliūno darbus nutraukè 1934 m. birželio 6 d. pučas.

Po $1934 \mathrm{~m}$. birželio 6 d. pučo kariuomenès vadovybès įstatymų kūrimo darbas nenutrūko, tik šikart jị tęsẻ ką tik Vyriausiojo štabo valdybos viršininku, o vèliau ir kariuomenès vadu tapęs plk. ltn. S. Raštikis - jam vadovaujant buvo parengtas ir nuo 1935 m. sausio $1 \mathrm{~d}$. ịsigaliojo Kariuomenès vadovybės įstatymas ${ }^{84}$. Kiek galima nustatyti iš archyvinių šaltinių, plk. S. Raštikiui ši įstatymą rengti padejo krašto apsaugos ministras gen. ltn. Petras Šniukšta ${ }^{85}$ ir aukšto rango karininkai - plk. Stasys

\footnotetext{
82 Ginkluotųjų pajègų valdymo karo metu ịstatymo projektas, $1934 \mathrm{~m}$. žiema (nurodama dokumente), LCVA, f. 929, ap. 5, b. 407, 1. 221-230.

83 Modestas Kuodys, Pulkininkas Balys Giedraitis, sud. Gintautas Surgailis, Lietuvos krašto apsaugos ministrai ir kariuomenés vadai, t. 2, p. 142; Vidmantas Jankauskas, Nepriklausomos Lietuvos generolai, Vilnius, 1998, p. 174-175.

84 Stasys Raštikis, Itvykiai ir žmonès, t. 4, Čikaga, 1972, p. 18.

85 Ten pat.
} 
Zaskevičius ${ }^{86}$, plk. J. Bobelis ${ }^{87}$ ir plk. ltn. Kazys Sprangauskas ${ }^{88}$. Rengiant ši ịstatymą buvo nustatytos aiškios politinès vadovybès nuostatos, kurios turèjo būti igyvendintos. Pirmiausia ginkluotosios pajègos turèjo būti atribotos nuo „partinių ir egoistinių užgaidų“, o ịstatymo pagrindu tapti „tautiškumas“. Respublikos Prezidento, krašto apsaugos ministro kariuomenès vadovavimo grandinejje turèjo būti akcentuota, kad „Prezidento valia - tai viskas“. Parengus ịstatymą turèjo būti išvengta didesnių pasikeitimų ginkluotųjų pajègų vadovybės organizacijoje, o taikos meto Krašto apsaugos ministerija sutvarkyta taip pat kaip ir karo metu ${ }^{89}$.

Prieš pradedant rengti ši ịstatymą buvo išanalizuota padetis to meto kariuomenès vadovybèje ir konstatuota, kad krašto apsaugos ministro, Vyriausiojo štabo viršininko ir kariuomenès vado santykiai priklauso nuo jų asmeninių santykių ir buvo reguliuojami vadovaujantis tik $1869 \mathrm{~m}$. Rusijos karo įstatymų rinkinio pirmosios dalies I-IV knygų nuostatomis $^{90}$. Tarp esminių ístatymą keisti vertusių aplinkybių buvo dvigubas Vyriausiojo štabo viršininko pavaldumas krašto apsaugos ministrui ir kariuomenès vadui ${ }^{91}$.

Kaip paaiškejjo tyrimo metu, ši problema buvo i̇sisenejusi. Dèl dvejopo Gen. štabo viršininko pavaldumo plk. K. Kleščinskis skundèsi jau 1922 m.92 Pasak šio ìstatymo rengèjų plk. S. Raštikio ir plk. J. Bobelio, 1935 m. paskelbtu kariuomenès vadovybès ịstatymu siekta nustatyti aiškias krašto apsaugos ministro ir kariuomenès vadas teises ir atsakomybès sritis $^{93}$, kurios buvo „ne visai pastovios ir dažnai keitèsi drauge su etatu

\footnotetext{
86 Raportas Vyriausiojo štabo viršininkui, 1934 m. birželio 23 d., LCVA, f. 929, ap. 5, b. $407,1.164-166$.

87 Jonas Aničas, Karo komendantas Kazys Bobelis, Vilnius, 2011, p. 134.

88 Raportas Generalinio štabo valdybos viršininkui, 1934 m. liepos 9 d., LCVA, f. 929, ap. 5 , b. $407,1.1$.

${ }^{89}$ Raportas Vyriausiojo štabo viršininkui, 1934 m. birželio 23 d., LCVA, f. 929, ap. 5, b. $407,1.164-166$.

90 Generalinio štabo I skyriaus viršininko raportas, 1934 m. liepos 9 d., LCVA, f. 929, ap. 5 , b.,407, 1. 1 .

91 Generalinio štabo I skyriaus viršininko raporto priedas Nr. 1a, 1934 m. liepos 9 d., LCVA, f. 929, ap. 5, b. 407, 1. 1.

92 Generalinio štabo viršininko pareiškimas, 1922 m. lapkričio 20 d., LCVA, f. 384, ap. 3, b. $344,1.134-13$.

93 Stasys Raštikis, Itvykiai ir žmonès, t. 4, Čikaga, 1972, p. 18.
} 
pakeitimais ${ }^{\text {“94 }}$. Taigi naujasis kariuomenès vadovybès įstatymas turèjo sureguliuoti svarbiausių politinių ir karinių pareigūnų santykius ir išspręsti ịsisenèjusias problemas.

Šis ịstatymas taip pat buvo rengiamas studijuojant užsienio valstybėse Lenkijoje, Estijoje, Latvijoje, Suomijoje ir Čekoslovakijoje - galiojančius tokio pat pobūdžio įstatymus ir juose ịtvirtintas nuostatas ${ }^{95}$. Istatymo versiją, remdamasis analogiškais Vokietijoje galiojusiais įstatymais, pateike ir Lietuvos pasiuntinys Vokietijoje plk. K. Škirpa ${ }^{96}$. Bet, kaip galime spręsti iš S. Raštikio atsiminimų, ịstatymo rengejus labiausiai domino Lenkijoje, Estijoje ir Latvijoje galiojantys ịstatymai ${ }^{97}$, tai rodo, kad lietuviškojo įstatymo rengèjai ypač domèjosi autoritarinių, o ne demokratinių režimų patirtimi.

Kaip ir anksčiau rengtuose projektuose, šikart didžiausios ir svarbiausios galios valdyti kariuomenę buvo sutelktos Respublikos Prezidento ir kariuomenès vado rankose, krašto apsaugos ministrui paliekant kariuomenès kontrolès funkcijas. Respublikos Prezidentas buvo paskelbtas vyriausiuoju ginkluotųjų pajègų vadu, kuriam suteikta teisė skelbti mobilizaciją ir demobilizaciją, pradèti ir stabdyti karo veiksmus, skirti ir atleisti viršininkus pulko vado ir aukštesnèmis teisèmis, priimti karininkus ¡̇ karo tarnybą ir atleisti iš jos, tvirtinti drausmès administravimo ir ūkio statutus. Jis taip pat turèjo teisę inicijuoti, prižiūrèti ir tvirtinti Valstybès gynybos tarybos nutarimus.

Krašto apsaugos ministras turèjo rūpintis kariuomenès tiekimo ir aprūpinimo reikalais, valdyti Krašto apsaugos ministerijos kreditus, skirti ir atleisti karininkus bataliono vado teisemis, skelbti Respublikos Prezidento įstatymus kariuomenei, prižiūrèti drausmę, kadangi drausmės kariuomenejje priežiūra buvo numatyta kariuomenès vadui. Kariuomenės vadas privalëjo visas ginkluotąsias pajègas rengti karui, tvirtinti mobilizacijos ir operacijų planus, mokymo ir taktikos statutus, nustatyti kariuomenès dislokaciją, parinkti vadus ir viršininkus, skirti ir atleisti karininkus bataliono vado ir pulko vado padejejejo tiesèmis, daryti pranešimus apie savo

\footnotetext{
94 Jurgis Bobelis, Kariuomenès vadovybès įstatymo sulaukus, Kardas, nr. 2, 1935 m. sausio 15 d., p. 28.

95 Stasys Raštikis, Kovose dèl Lietuvos, t. 1, Čikaga, 1956, p. 335-336.

96 Plk. K. Škirpos raštas „Pagrindiniai bruožai karo vadovybės organizacijos taikos meto“ (be datos), LCVA, f. 929, ap. 5, b. 407, 1. 248-253.

97 Stasys Raštikis, Kovos dèl Lietuvos Nepriklausomybès, t. 1, Vilnius, 1990, p. 335-336.
} 
darbą krašto apsaugos ministrui ir Respublikos Prezidentui ${ }^{98}$. Pagrindinès šio įstatymo nuostatos atskleidžia, kad daugiausia kariuomenès valdymo svertų buvo sutelkta Respublikos Prezidento ir kariuomenès vado rankose, o krašto apsaugos ministro galių sumenkinimas ji pavertẻ kariuomenę ir prezidentą aptarnaujančiu biurokratu. Šiomis nuostatomis ịstatymas panašus $\mathfrak{i}$ gen. ltn. P. Kubiliūno rengtus analogiško įstatymo projektus, kuriuose taip pat sumenkintas krašto apsaugos ministro vaidmuo.

Taip pat pažymètina, kad $1935 \mathrm{~m}$. kariuomenès vadovybès įstatymas visiškai eliminuoja bet kokị vyriausybès vaidmenị kariuomenès valdyme, o juk $1922 \mathrm{~m}$. demokratiniu valstybès raidos laikotarpiu parengtame Ginkluotųjų pajègų ir jų ịstaigų valdymo ịstatymo projekte vyriausybė teikè Prezidentui vyriausiojo karo vado kandidatūrą ir suteikè teisę duoti jam „bendrus nurodymus“ kariuomenei krašto gynybos reikalais". Taigi, 1935 m. išleistas kariuomenès vadovybès įstatymas, nors ir aiškiai apibrèžiantis kariuomenès vado, krašto apsaugos ministro ir Respublikos Prezidento teises ir pareigas, kartu liudijo ir aiškų kariuomenès valdymo posūkị autoritarinių tendencijų link.

Kai kurios šio įstatymo nuostatos, apibrèžiančios Respublikos Prezidento galias, buvo įtvirtintos valstybès Konstitucijoje. Remiantis Konstitucija, Respublikos Prezidentas galejo skirti ir atleisti kariuomenès vadą, vadovauti prie Respublikos Prezidento gynybos reikalams spręsti ìsteigtai Valstybès gynimo tarybai. Jis turèjo teisę spręsti dèl mobilizacijos, taikos ir karo veiksmų paskelbimo ar atšaukimo Ministrų Tarybos siūlymu ${ }^{100}$. Reikètų atkreipti demesị i šimtas trisdešimt šeštame Konstitucijos paragrafe ịtvirtintą nuostatą, kad kariuomenès vadui byla dèl tarnybinio nusikaltimo gali būti keliama tik su Respublikos Prezidento sutikimu ${ }^{101}$. Kartu su Prezidento teise vienašališkai skirti kariuomenès vadą šią Konstitucijos nuostatą reikètų vertinti kaip pabrèžiančią kariuomenès vado priklausomybę nuo Prezidento ir kariuomenès vadui suteikiančią pastarojo teisinę globą. Taigi, $1935 \mathrm{~m}$. kariuomenès vadovybès istatymas ir $1938 \mathrm{~m}$. Konstitucijos nuostatos galutinai ittvirtino autorita-

\footnotetext{
98 Kariuomenès vadovybès įstatymas, Kardas, nr. 1, 1935 m. sausio 15 d., p. 29.

99 Ginkluotųų pajègų ir jų j̇staigų valdymo įstatymo projektas, $1922 \mathrm{~m}$. kovo $15 \mathrm{~d}$., LCVA, f. 384, ap. 3, b. 344, 1. 204-206.

${ }^{100}$ Kazimieras Valančius, Lietuvos valstybès konstitucijos, Vilnius, 1989, p. 26-27.

101 Ten pat.
} 
rinio pobūdžio politinès ir karinès valstybès vadovybès santykius. Taip buvo sureguliuotas ir teisiškai įtvirtintas A. Smetonos ir svarbiausios jo autoritarinio režimo atramos - kariuomenès prioritetas.

\section{IŠVADOS}

- Teisiškai neapibrèžti ir nesureguliuoti svarbiausių valstybės politinès valdžios institucijų - Respublikos Prezidento, Seimo, ministro pirmininko, krašto apsaugos ministro ir kariuomenès vado - santykiai sudarè prielaidas politinèms jẻgoms įtraukti kariuomenę $\mathfrak{i}$ tarpusavio politinès konkurencijos lauką ir paversti valstybès vidaus politikos veiksniu.

- Tai, kad iki 1935 m. nebuvo aukščiausios karinès vadovybès ịstatymo, lèmé sudètingą kariuomenès valdymą ir kai kurių kariuomenės viršininkų dvejopą pavaldumą, o politinès ir karinès vadovybès santykius padarè priklausomus ne nuo teisinių procedūrų, o nuo karo vadų ir politikų asmeninių ryšių. Tai ypač išryškèjo A. Smetonos autoritarinio režimo laikotarpiu.

- 1922 m. Konstitucijoje ịtvirtinta demokratinio kariuomenès valdymo nuostata negalèjo būti igyvendinta, kadangi demokratiniu valstybès egzistavimo laikotarpiu nebuvo priimtas įstatymas, kuris suteiktų teisę piliečiams per jų demokratiškai išrinktas institucijas valdyti ir kontroliuoti ginkluotąsias pajègas. Iš dalies tai lèmè, kad 1935 m. Lietuvos kariuomenès vadovybès ịstatymas buvo parengtas remiantis Rusijos imperijos karo teise ir sudarè prielaidas egzistuoti autoritarinèms santvarkoms būdingiems politinès ir karinès valdžios santykiams tarpukario Lietuvoje.

Iteikta $2017 \mathrm{~m}$. gruodžio $6 \mathrm{~d}$. 


\title{
LES EFFORTS JURIDIQUES POUR REGLEMENTER LA SUBORDINATION DU COMMANDANT MILITAIRE SUPREME ET DU CHEF DE L'ARMEE AU MINISTRE DE LA DEFENSE, AU PREMIER MINISTRE ET AU PRESIDENT DE LA REPUBLIQUE EN LITUANIE EN 1918-1940
}

\author{
Kęstutis KILINSKAS \\ Université de Vilnius
}

Larticle étudie la réglementation juridique de la subordination du commandement de l'armée (commandant militaire suprême, chef de l'armée et chef de l'état-major général) au pouvoir politique de l'État (ministre de la Défense, président du Seimas et Président) entre 1918 et 1940. Pendant l'existence de la République de Lituanie de l'entre-deux-guerres, nous pouvons distinguer les périodes des luttes de l'indépendance et de réglementation démocratique puis autoritaire des relations entre les autorités politiques et militaires.

Pendant les luttes d'indépendance, l'évolution de la réglementation juridique de la subordination entre les fonctionnaires supérieurs de l'armée, le ministre de la Défense et le commandant militaire suprême a été surtout influencée par le conflit entre le Conseil d'État et le Gouvernement qui a eu lieu entre les forces politiques de droite et de gauche. Ignorant les principes fondamentaux de la Constitution provisoire du 2 novembre 1918, le Gouvernement a tenté de prendre la direction de l'armée entre ses mains; mais, après son échec et la victoire de la droite dans cette lutte, les fondements fondamentaux de la Constitution provisoire ont été corrigés le 4 avril 1919 et le commandant militaire suprême est devenu subordonné au Président. La subordination du commandant militaire suprême au Président n’a pas apporté une plus grande stabilité dans les relations entre le pouvoir politique et l'armée, et elle n'a pas fait cesser les conflits entre les politiques et les officiers, toutefois elle a inspiré le corps des officiers à préparer une loi qui séparerait clairement les limites de compétence et les sphères d'activité des politiques et des militaires et réglementerait leur interaction. On na réussi à adopter cette loi que le 7 mai 1920, mais elle ne séparait que les fonctions du ministre de la Défense et du commandant militaire suprême.

Pendant la période du Seimas constituant a été préparé un projet de loi sur les forces armées et l'administration de leurs institutions qui avait des orientations démocratiques claires. La direction des forces armées était alors 
répartie entre les institutions démocratiquement formées de l'administration de l'État : le Président, le cabinet des ministres et les chefs de l'armée, tandis qu'était créé auprès du ministre de la Défense un conseil de guerre, composé de fonctionnaires civils et militaires. Mais cette loi n’a pas été débattue ni adoptée. Les relations entre le commandement militaire et politique pendant la période démocratique de l'État ont été réglementées uniquement par la Constitution de 1922.

Pendant la période autoritaire de l'État ont été instaurées des dispositions autoritaires de direction de l'armée qui se reflètent dans les Constitutions de 1928 et 1938 ainsi que la loi de 1935 sur le commandement de l'armée. Ces lois élargissaient les pouvoirs du Président et du chef de l’armée pour diriger l’armée, diminuant ainsi le rôle du ministre de la Défense dans la direction de l'armée, et soulignant la relation étroite entre le Président A. Smetona et le chef de l'armée le colonel S. Raštikis. Ainsi a été concentré entre les mains de ces personnes le plus grand pouvoir juridique de direction de l'armée. 


\title{
LEGAL EFFORTS TO REGULATE SUBORDINATION OF THE COMMANDER-IN-CHIEF AND THE COMMANDER OF THE ARMY TO THE MINISTER OF NATIONAL DEFENCE, THE PRIME MINISTER AND THE PRESIDENT OF THE REPUBLIC OF LITHUANIA IN 1918-1940
}

\author{
Kęstutis KILINSKAS \\ Vilnius University
}

The article deals with the legal regulation of subordination of the military commanders (the Commander-in-chief, the Commander of the Army, and the Chief of the General Headquarters) to the political state authority (the Minister of National Defence, the Speaker of the Seimas, and the President) in 1918-1940. In the interwar period of the Republic of Lithuania, we can distinguish between the phase of struggle for independence and the democratic and authoritarian phases of regulation of the political and military authority relations.

During the period of independence struggles, changes in the legal regulation of the subordination of the highest military officers - the Minister of National Defence and the Commander-in-chief - were most significantly influenced by the conflict between the State Council and the Government, which was caused by the encounter of right and left political forces in the situation where the Government despite the framework statements of the Provisional Constitution of 2 November 1918 unsuccessfully attempted to take over control of the Army and, having gained the support of the right-wing political forces, on 4 April 1919, managed to make corrections in the Provisional Constitution, according to which the Commander-in-chief became subordinate to the President.

The subordination of the Commander-in-Chief to the President did not lead to greater stability in relations between the political powers and the Army, and did not stop the conflicts between politicians and military officers, nevertheless, it inspired the military officers to draw up a law that clearly distinguished between the competences of political and military officials, the areas of their activity and regulated interaction. The law was approved on 7 May 1920; however, it only described the separate duties of the Minister of National Defence and the Commander-in-Chief.

During the period of the Constituent Seimas, a draft law on the control of the Armed Forces and their institutions was prepared. The draft law was 
characterized by obvious democratic tendencies, which meant that the control of the Armed Forces could have been shared by the democratically elected state powers, President, Cabinet of Ministers and military commanders, and the Military Council composed of civilian and military officials could have been established at the National Defence Ministry, however, the draft law was not debated and approved. For this reason, relations between the military and political leadership during the democratic period of the development of the state were regulated, from as late as 1922, with the approval of the constitutional provisions.

In the authoritarian period of the state, the authoritarian provisions of the Army control were implemented, which was reflected by the Constitution of 1928 and the Law on the Lithuanian Armed Forces of 1935. The abovementioned laws extended the powers of the President and the Commander of the Army to control the army thus undermining the role of national defence in the management of the Army and supporting the close collaboration of President A. Smetona and Colonel S. Raštikis, the Commander of the Army. The greatest legal power to control the Army was in the hands of these persons. 